\title{
18. PRELIMINARY RESULTS OF HIGH-RESOLUTION POLLEN ANALYSES OF SELECTED PLEISTOCENE INTERVALS FROM HOLES 798A, 798B, AND 798C ${ }^{1}$
}

\author{
Linda E. Heusser ${ }^{2}$
}

\begin{abstract}
Results of preliminary pollen analyses of 280 samples from selected intervals of cores from Hole 798 on the Oki Ridge in the Sea of Japan (Sections 798A-1H-1 through 798A-3H-3, 798B-1H, 798B-13H1 through 798B-15H-8, and 798C-1H-1 through $798 \mathrm{C}-1 \mathrm{H}-3$ ) indicate that (1) diagnostic pollen types of the vegetation of Japan are abundant and well-preserved in sediments deposited over the last 1.4 m.y.; (2) the concentration, preservation, and composition of pollen in the rapidly deposited sediments of Site 798 provide a basis for high-resolution (on the order of $\sim 500$-year intervals) pollen stratigraphy in Pliocene-Pleistocene Japan Sea sediments; (3) the pollen stratigraphy of sediments from Site 798 can be directly correlated with pollen stratigraphies of correlative ages onshore; and (4) the development of continuous, directly correlative Pliocene-Pleistocene terrestrial/marine paleoclimatic records from sediments deposited at Site 798 will provide a continuous high-resolution record of northeast Asian marine and terrestrial paleoenvironmental changes for the past $\sim 2.4 \mathrm{Ma}$.
\end{abstract}

\section{INTRODUCTION}

A prime objective at Site 798 was to develop a Neogene paleoceanographic reference section. Taken close to the main island of Japan, the retrieved section, in which sedimentation rates average $120 \mathrm{~m} / \mathrm{m} . y$. , apparently provided a unique opportunity to develop a high-resolution terrestrial paleoenvironmental record (Koroneva, 1961; Morley et al., 1986). My initial objective was to evaluate the suitability of pollen in sediments from Hole 798A for detailed paleoecological and biostratigraphic analyses. Because the preliminary pollen analyses suggested that several meters of the topmost sediment had not been retrieved in Hole 798A and the Initial Reports (Ingle, Suyehiro, von Breymann, et al., 1990) showed that Holes 798B and $798 \mathrm{C}$ had retrieved the mud/water interface, the uppermost sediment from Holes 798B and 798C was also analyzed for pollen in order to obtain a more complete Quaternary overview.

\section{Study Area}

Site 798 , in the southeastern Sea of Japan $\left(37.038^{\circ} \mathrm{N}, 134.80^{\circ} \mathrm{E}\right.$, $900 \mathrm{mbsf}$ ) is on the Yamato Rise, a fault-bounded topographic high located $\sim 100 \mathrm{~km}$ west of Honshu, Japan (Fig. 1). The proximity of this site to Japan suggests, and empirical evidence confirms, that the primary source of pollen on the Oki Ridge is the vegetation of Japan (Heusser, 1977, 1988; Heusser and Morley, 1985; Sarro, 1991). On the back side of Japan, potential natural montane vegetation, which varies with latitude and altitude, consists of evergreen and deciduous broadleaf and coniferous forests (Numata, 1974; Heusser, this volume). Characteristic dominants of the warm-temperate forests include evergreen members of the Fagaceae, such as Quercus and Castanopsis, along with conifers such as Cryptomeria japonica, Podocarpus, and the secondary species Pinus densiflora. Temperate, deciduous broadleaf forests are characterized by Quercus/Fagus associations in which Pinus and Cryptomeria are present. Conifers (Picea, Abies and Tsuga) along with Betula and Alnus are associated with subalpine elevations (1500-2000 m above sea level) (Ohwi, 1984).

\footnotetext{
${ }^{1}$ Pisciotto, K. A., Ingle, J. C. Jr., von Breymann, M. T., Barron, J., et al, 1992, Proc. ODP, Sci. Results, 127/128, Pt.1: College Station, TX (Ocean Drilling Program).

Lamont-Doherty Geological Observatory of Columbia University, Palisades, NY 10964, U.S.A.
}

\section{Material and Methods}

All three holes at Site 798 (Fig. 1, Table 1) were sampled for pollen. From the silty and siliceous silty clays of the upper $27 \mathrm{mbsf}$ of Hole $798 \mathrm{~A}$ (Samples 798A-1H-1, 1-3 cm, through 798A-3H-3, 76-78 cm), 177 samples for joint pollen/stable isotope high-resolution paleoclimatic study were taken at consecutive $\sim 10 \mathrm{~cm}$ intervals. Forty samples were processed from the uppermost sediment from Holes 798B and 798C. Samples from the upper $125 \mathrm{~cm}$ of Core $798 \mathrm{~B}-1 \mathrm{H}$ were taken from contiguous intervals of whole-round-cores (Cragg, this volume). The sampling intervals from Hole $798 \mathrm{C}$ are more variable and about six times as large as the sampling interval in Core 798B-1H. Samples 798B-13H-1, 0-30 cm, through 798B-15H-8, 30-60 cm, are splits of 63 contiguous "scrape" samples that integrate $\sim 30 \mathrm{~cm}$ in depth $(\mathbf{P}$. DeMenocal, pers. comm.).

Sample preparation procedures and methodology used in pollen identification are described elsewhere (Heusser, this volume). Pollen data, selected from the pollen data sets on file in the ODP databank, are here presented as percentages of the preliminary pollen counts ( $>100$ pollen grains/sample, and as concentration (pollen/grams dry weight sediment $=$ gdws). Because of the preliminary nature of the pollen data, pollen influx was not determined nor were the pollen diagrams divided into pollen assemblage zones.

\section{Chronostratigraphy}

Unless otherwise stated, age models used in this paper are based on sedimentation rates of $\sim 12 \mathrm{~cm} / \mathrm{k}$.y. (Table 2). The age of the uppermost sediment recovered in Holes $798 \mathrm{~B}$ and $798 \mathrm{C}$ was presumed to be Recent because the mud line was apparently retrieved (Ingle, Suyehiro, von Breymann, et al., 1990). Estimates of the depth of uppermost sediment in Hole 798A ranged from 1 to $4 \mathrm{~m}$ below the mud/water interface (Ingle, Suyehiro, von Breymann, et al., 1990). The chronology of samples from the upper $30 \mathrm{mbsf}$ of Hole $798 \mathrm{~A}$ is further complicated by the nonretrieval of sediment between 13.5 and 18.5 mbsf (Ingle, Suyehiro, von Breymann, et al., 1990). Comparison of the pollen stratigraphy of Cryptomeria from Section 798A-1H-1 with that of nearby piston cores V28-265 and RC14-99 (Fig. 2, Table 2) suggests that the age of the uppermost sediment in Hole 798A may be as old as 65 k.y. (Morley et al., 1986). Comparison of the pollen stratigraphy of the uppermost sediment deposited at Holes $798 \mathrm{~A}, 798 \mathrm{~B}$, and $798 \mathrm{C}$ with pollen stratigraphy from piston core V28-265 indicates that the uppermost sediment retrieved in Hole 798B and 798C-1H is Holocene (Morley et al., 1986; Sarro, 1991). 


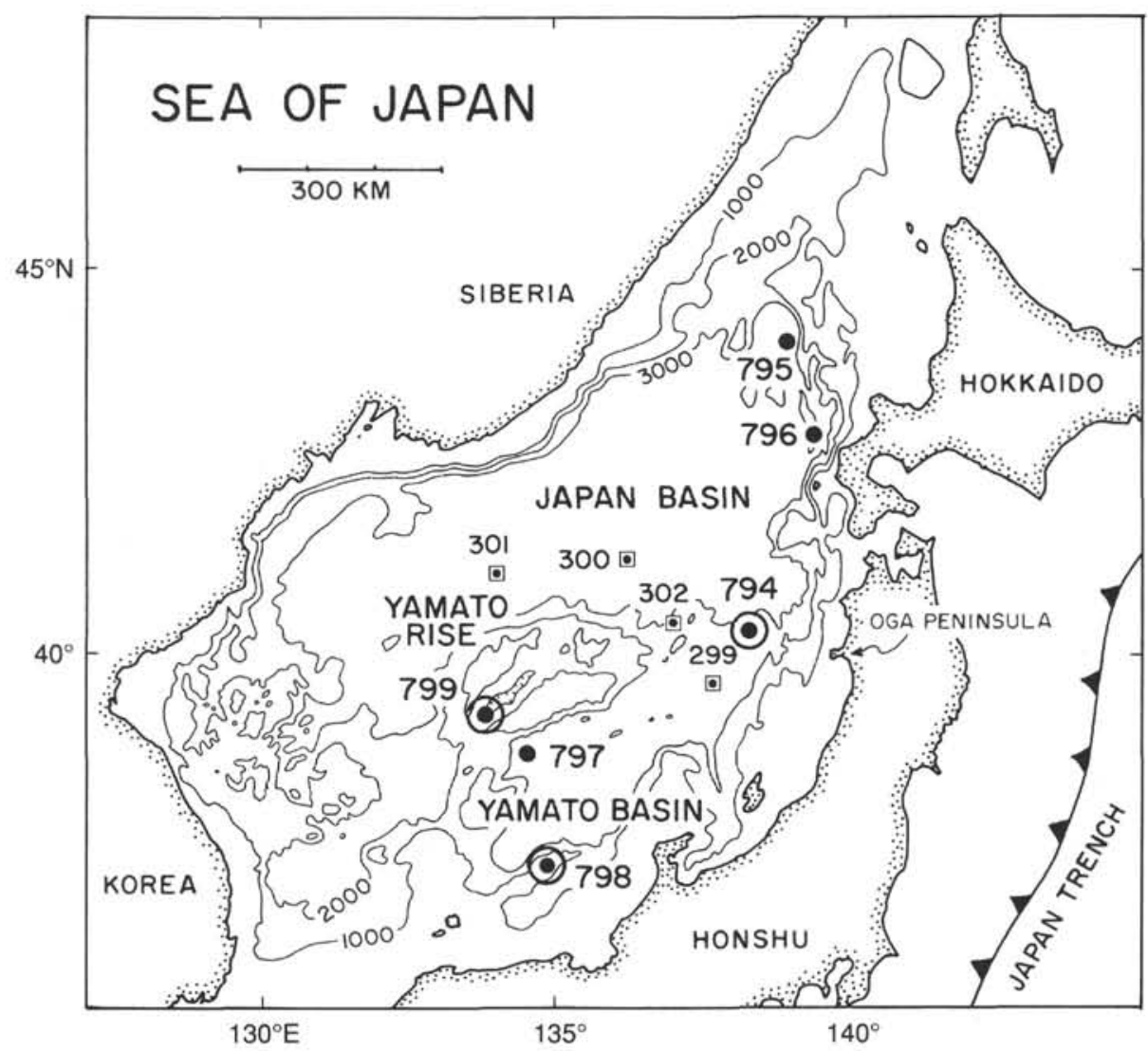

Figure 1. Location map of Site 798 in the Japan Sea. Bathymetry in meters.

Table 1. Location data for Holes 798A, 798B, and 798C, and piston cores RC14-99 and V28-265.

\begin{tabular}{llll}
\hline Hole or core & $\begin{array}{c}\text { Latitude } \\
\left({ }^{\circ} \mathrm{N}\right)\end{array}$ & $\begin{array}{c}\text { Longitude } \\
\left({ }^{\circ} \mathrm{E}\right)\end{array}$ & $\begin{array}{l}\text { Depth } \\
(\mathrm{mbsf})\end{array}$ \\
\hline $798 \mathrm{~A}$ & 37.03832 & 134.79976 & 903 \\
$798 \mathrm{~B}$ & 37.03848 & 134.79961 & 900 \\
$798 \mathrm{C}$ & 37.03846 & 134.07991 & 900 \\
Core RC14-99 & 36.58 & 147.56 & 5652 \\
Core V28-265 & 36.17 & 134.34 & 1218 \\
\hline
\end{tabular}

Mean spacing of samples analyzed for pollen from Site 798 ranges from $800-1000$ k.y. in Hole 798A to 2500 k.y. in Hole 798C. The average time between Samples 798B-1H-1, 0-5 cm, and 798B-1H-1, $125-130 \mathrm{~cm}$, is $\sim 400-500$ k.y., and the sampling interval in Cores $798 \mathrm{~B}-13 \mathrm{H}$ through $798 \mathrm{~B}-15 \mathrm{H}$ is about five times as large, $\sim 2500 \mathrm{k} . \mathrm{y}$.

\section{Results}

Pollen preservation was generally excellent, and all 280 samples processed yielded initial pollen counts of over 100 pollen grain/gdws. Concentration of pollen appears to vary periodically over a tenfold range from 4000 to 60,000 grains/gdws (Fig. 3). In samples from Site 798 , as in other sites in the Sea of Japan (Heusser, this volume), organic matter (possibly charred plant fragments) and pyrite were often abundant. Variable quantities of dinoflagellates and fungal spores were present, microforaminifers were less numerous, and reworked Mesozoic or Paleogene pollen and spores were rare.

Summary pollen statistics from the upper sediments from Cores 798B-1H and 798C-1H show that conifers (Pinus, Picea, and Cryptomeria) are numerically more important than the representative deciduous taxa, Quercus and Alnus. Pollen statistics from Cores
Table 2. Age-depth datums used to establish the preliminary age models for Site 798 .

\begin{tabular}{|c|c|c|c|c|c|}
\hline $\begin{array}{l}\text { Depth } \\
\text { (mbsf) }\end{array}$ & $\begin{array}{l}\text { Age } \\
(\mathrm{Ma})\end{array}$ & $\begin{array}{l}\text { Sedimentation rate } \\
(\mathrm{m} / \mathrm{m} . \mathrm{y} .)\end{array}$ & $\begin{array}{l}\text { Mean dry bulk } \\
(\mathrm{cm} / \mathrm{k} . \mathrm{y})\end{array}$ & $\begin{array}{l}\text { density } \\
\left(\mathrm{g} / \mathrm{cm}^{3}\right)\end{array}$ & $\begin{array}{l}\text { Accumulation rate } \\
\left(\mathrm{g} / \mathrm{cm}^{2} / \mathrm{k} . \mathrm{y} .\right)\end{array}$ \\
\hline 0 & 0 & & & & \\
\hline & & 120 & 12.0 & 0.71 & 8.52 \\
\hline 39 & 0.34 & 125 & 12.5 & 0.78 & 9.75 \\
\hline 54.54 & 0.46 & & & & \\
\hline 75.34 & 073 & 91 & 9.1 & 0.81 & 7.37 \\
\hline & & 84 & 8.4 & 0.75 & 6.33 \\
\hline 90.55 & 0.91 & 45 & 4.5 & 0.82 & 3.69 \\
\hline 94. & 0.98 & 45 & 4.5 & 0.75 & 9.15 \\
\hline 119.91 & 1.20 & 122 & 12.2 & 0.73 & 11.68 \\
\hline 200.08 & 1.66 & & & & \\
\hline
\end{tabular}

798B-1H and 798C-1H are generally similar and differ from the summary statistics from Hole 798A and Cores 798B-13H through $15 \mathrm{H}$ (Table 3 ). Variations in the relative abundance and concentration of the most frequently occurring diagnostic taxa in sediments from the Sea of Japan are shown in both the depth and time domain (Figs. 2-8). Some pollen taxa are illustrated in groups that have similar ecological parameters. For example, in cool temperate and boreal environments, such as the subalpine zone of central Japan or the central mountain ranges of Hokkaido, pollen of Picea, Abies, and Tsuga is more abundant that of Quercus, Fagus, and other deciduous types (Tsukada, 1988). Deciduous pollen types include Fagus, Ulmus, Juglans, and Tilia. Betula and Alnus are secondary or pioneer species, and herbs (members of the Compositae, Chenopodiaceae, Gramineae, and Cyperaceae) generally reflect open environments. 

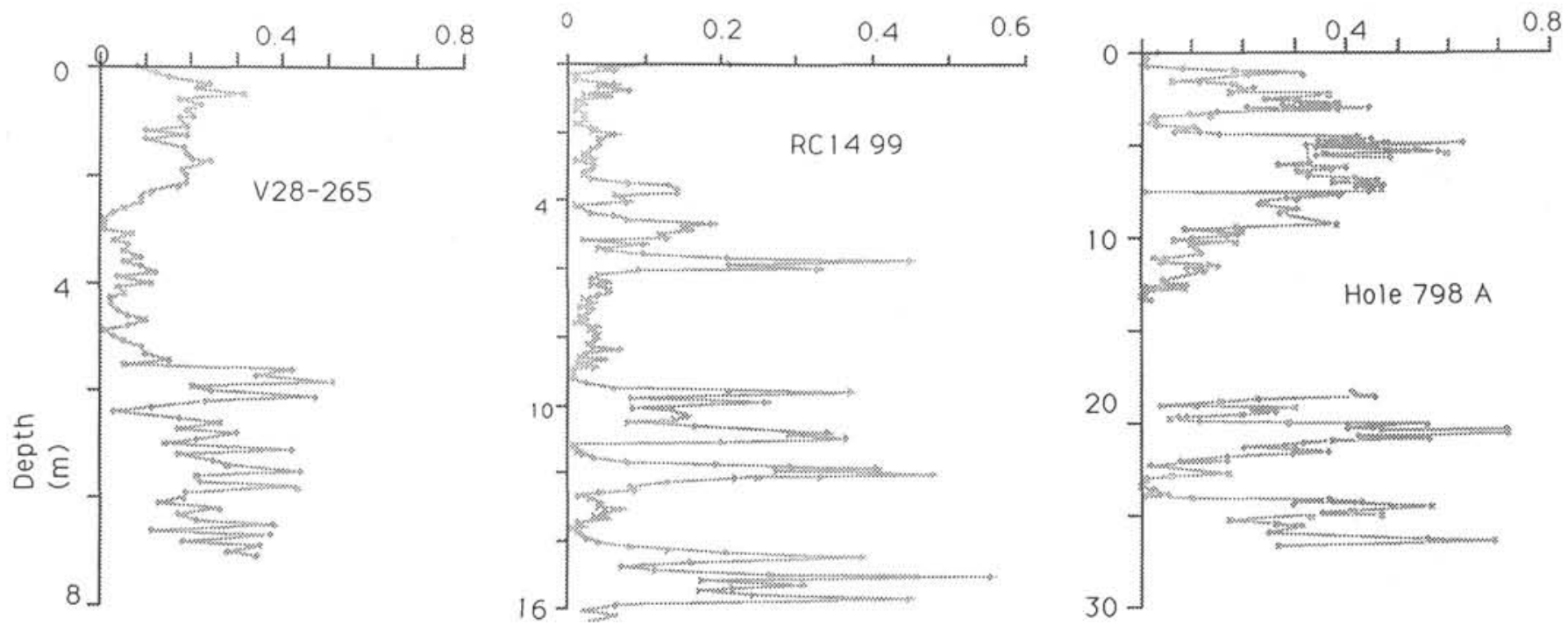

Figure 2. Percentages of Cryptomeria plotted against depth in the uppermost sediment from piston cores V28-265 and RC14-99 and from Hole 128-798A (Morley et al., 1986; Sarro, 1991; Heusser and Morley, in press).

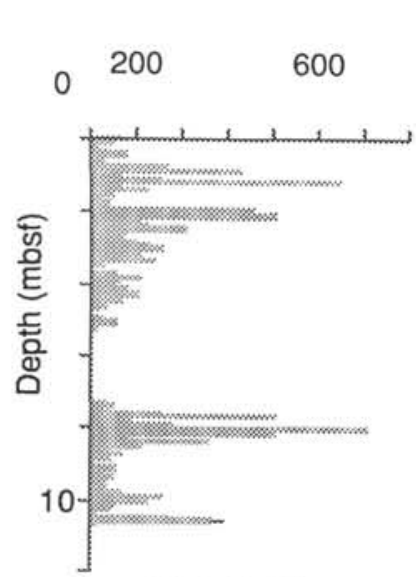

Hole 798A

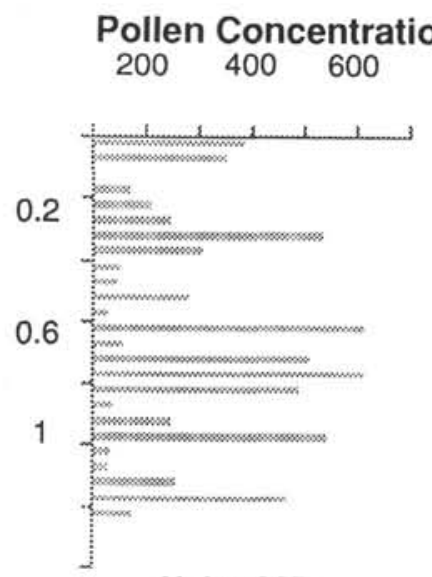

Hole 798B
120

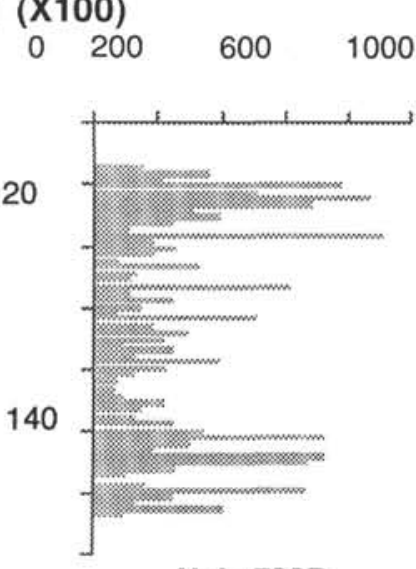

Hole 798B

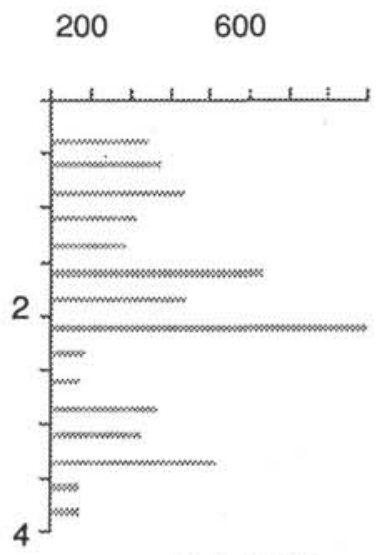

Hole $798 \mathrm{C}$

(0-27 mbsf)

(114-141 mbsf)

(0-4 mbsf)

Figure 3. Pollen concentration (pollen grains/gram dry weight sediment) $\times 100$ in samples from Sections 798A-1H through 798A-3H, 798B-1H, 798B-13H through $798 \mathrm{~B}-15 \mathrm{H}$, and $798 \mathrm{C}-1 \mathrm{H}$.

In the upper $30 \mathrm{~m}$ of Hole $798 \mathrm{~A}$ (Fig. 4), conifers, Pinus, Cryptomeria + other Taxodiaceae, and to a lesser extent Picea + Abies + Tsuga, are the most important pollen types (Table 3 ). Rhythmic fluctuations occur in the relative abundance of the major pollen taxa. Values of Pinus and Cryptomeria change abruptly from $<10 \%$ to $\sim 80 \%$, except for the extended ramplike rise of Cryptomeria between $\sim 14$ and $10 \mathrm{mbsf}$, just above a core break. Sediments from the top of the core (Sample 798A$1 \mathrm{H}-1,1-5 \mathrm{~cm}$ ) exhibit peak values of Pinus, Picea + Abies + Tsuga, herbs and Betula + Alnus, and minimal percentages of Cryptomeria and related types, Quercus and other deciduous types.

Maximum amounts of pollen from broadleaf trees (represented here by Quercus) occur at the base of Section 798B-1H-1. Profiles of Cryptomeria and Picea + Abies + Tsuga basically form a broad arc, reaching a maximum of $\sim 25 \%$. Herbs are relatively unimportant. Concentration of these pollen types generally conforms with patterns seen in the percentage data.
Structure of the pollen data from Section $798 \mathrm{C}-1 \mathrm{H}-1$ is bipartite: a lower assemblage in which values of Picea + Abies + Tsuga and of herbs are high, and an upper assemblage dominated by Cryptomeria and Quercus (Fig. 5, Table 3). Comparison of percentages of Cryptomeria in Core 798C-1H with nearby piston core V28-265 (Fig. 2) clearly shows the similarity in the pollen profiles of the upper $4 \mathrm{~m}$ in these two cores. Total pollen concentration in Core $798 \mathrm{C}-1 \mathrm{H}$ reaches maximum values midway in the section (Fig. 3). Age plots of these percentage data (Fig. 6) show that the division between the Cryptomeria- and Picea-dominated pollen assemblages occurs at $20 \mathrm{k} . \mathrm{y}$, the last glacial maximum.

In Cores $798 \mathrm{~B}-13 \mathrm{H}$ through $15 \mathrm{H}$, the sample interval is about six times as large as that in Core 798B-1H; however, the basic patterns of change in pollen concentration (Fig. 3) and in the diagnostic pollen types seen in the uppermost sediments from this hole (Fig. 5) are similar to those seen in pollen data from sediment deposited 114 
Table 3. Summary of pollen statistics from Holes 798A, 798B, and 798C.

\begin{tabular}{|c|c|c|c|c|c|c|}
\hline Hole & Taxa & Minimum & Maximum & Mean & $\begin{array}{l}\text { Standard } \\
\text { deviation }\end{array}$ & Standard error \\
\hline \multicolumn{7}{|l|}{ Hole 798A } \\
\hline & Pinus & 0.00 & 0.66 & 0.17 & 0.16 & 0.012 \\
\hline & Picea & 0.00 & 0.15 & 0.03 & 0.03 & 0.003 \\
\hline & Cryptomeria & 0.00 & 0.71 & 0.23 & 0.18 & 0.013 \\
\hline & Quercus & 0.00 & 0.33 & 0.10 & 0.18 & 0.013 \\
\hline & Alnus & 0.00 & 0.28 & 0.06 & 0.05 & 0.003 \\
\hline \multicolumn{7}{|l|}{ Hole 798B } \\
\hline & Pinus & 0.39 & 0.76 & 0.52 & 0.09 & 0.020 \\
\hline \multirow{4}{*}{$0-1.2 \mathrm{~m}$} & Picea & 0.00 & 0.04 & 0.01 & 0.01 & 0.002 \\
\hline & Cnyptomeria & 0.05 & 0.23 & 0.13 & 0.05 & 0.010 \\
\hline & Quercus & 0.06 & 0.27 & 0.14 & 0.05 & 0.011 \\
\hline & Alnus & 0.00 & 0.01 & 0.00 & 0.00 & 0.001 \\
\hline \multicolumn{7}{|l|}{ Hole 798B } \\
\hline & Pinus & 0.07 & 0.54 & 0.18 & 0.11 & 0.014 \\
\hline \multirow[t]{4}{*}{$110-120 \mathrm{~m}$} & Picea & 0.00 & 0.27 & 0.07 & 0.06 & 0.007 \\
\hline & Cnptomeria & 0.01 & 0.82 & 0.18 & 0.17 & 0.022 \\
\hline & Quercus & 0.02 & 0.43 & 0.14 & 0.09 & 0.011 \\
\hline & Alnus & 0.00 & 0.13 & 0.03 & 0.03 & 0.003 \\
\hline \multicolumn{7}{|l|}{ Hole $798 \mathrm{C}$} \\
\hline & Pinus & 0.13 & 0.67 & 0.44 & 0.15 & 0.040 \\
\hline & Picea & 0.00 & 0.34 & 0.12 & 0.11 & 0.030 \\
\hline & Cryptomeria & 0.00 & 0.22 & 0.08 & 0.07 & 0.017 \\
\hline & Quercus & 0.00 & 0.46 & 0.16 & 0.12 & 0.030 \\
\hline & Alnus & 0.00 & 0.09 & 0.02 & 0.02 & 0.005 \\
\hline
\end{tabular}

through $142 \mathrm{mbsf}$ (Fig. 7). The upper $5 \mathrm{~m}$ (113.65 to $118.65 \mathrm{mbsf}$ ) is distinguished by maximum amounts of Cryptomeria (Table 3 ). When plotted to age (Fig. 8), pollen data from Cores 798B-13H through $15 \mathrm{H}$ show two major cycles (between 1.14 and $1.18 \mathrm{Ma}$ and between 1.2 and 1.24 Ma.) overlain by higher frequency fluctuations.

\section{SUMMARY}

\section{Evaluation of Pollen in Site 798}

Preservation of pollen in the 280 samples analyzed from Site 798 is excellent, even when pollen concentration is low. Pollen concentration in older sediments (e.g., Cores 798B-13H through $15 \mathrm{H}$ ) is the same as or greater than that of the last 10,000 years (Core 798B-1H) (Fig. 4). In sediments from Site 798, high pollen concentration is often, but not always, associated with high percentages of Cryptomeria deposited during nonglacial intervals, as recorded elsewhere in the northwest Pacific and in Japan (Fuji, 1988; Heusser and Morley, in press). Although pollen concentration in North Pacific surface samples is associated with high organic content (Heusser, 1977), in Section 798B-13H-1 through 15H-8, correlation between pollen concentration and organic carbon is low $(r=0.15)$. Pollen concentrations in sediments deposited on the Oki Ridge obviously reflect variations in many factors, ranging from the effect of climate on pollen sources to marine sedimentation. Pollen influx data might be useful in attempting to separate pollen-related factors from other marine sedimentary and post-depositional variables; however, without high-resolution age models for the intervals sampled, flux provides little more information than pollen concentration (Sancetta et al., unpubl. data).

\section{Paleoenvironmental Reconstructions}

\section{Vegetation}

The paleoenvironments reconstructed from this initial survey of pollen from Leg 128 are based on present northeast Asian marine pollen/vegetation relationships (Heusser and Morley, 1985; Heusser, this volume). Late glacial and Holocene vegetation on the west coast of Japan, inferred from pollen assemblages in Cores 798B-1H and $798 \mathrm{C}-1 \mathrm{H}$, shifted rapidly over a period of a few thousand years from full-glacial, open forests in which Pinus, Picea, Tsuga, and Abies were important, to mixed forests in which Quercus and Cryptomeria contributed significantly (Figs. 5 and 6). During the last glacial maxi- mum, the increased abundance of herbs and Betula suggests that forests were open, herbaceous environments expanded, and vegetation associations frequently disturbed. Broadleaf elements were always present, and arctic/alpine indicators, such as Selaginella selaginoides, were not. As reconstructed from pollen in the Sea of Japan and in numerous pollen diagrams from southwestern Japan (Miyoshi et al., 1976; Miyoshi, 1989a,b), glacial vegetation on the coast of western Japan would be characterized as cool temperate or temperate. There is no evidence of complete displacement of warm temperate vegetation, nor of the development of taiga (deciduous conifer forest) or tundra; therefore in southern Japan, and possibly in southwestern Japan, components of warm temperate vegetation apparently coexisted with temperate elements during the last and preceding glaciations. Fluctuations between the two end-members of the vegetational spectrum just described-vegetation in which Cryptomeria and broadleaf trees or in which Picea + Abies + Tsuga dominate-characterize the intervals between 0.065 and $0.2 \mathrm{Ma}$ and between 1.14 and $1.26 \mathrm{Ma}$ (Figs. 7 and 8). The various Pleistocene vegetation associations implied by these marine pollen assemblages resemble the temperate and cool temperate vegetation formations of the last 20-30 k.y., in which there is no indication of expanded subtropical forests or subarctic taiga and tundra on the coast of southwestern Japan. Vegetational reconstructions from presumably correlative pollen data are comparable in composition (Tsukada, 1983, 1988; Kondo et al., 1984; Fuji, 1988; Momohara et al., 1990).

\section{Climatic Interpretation of Pollen Data from Site 128}

Based on the assumption that present pollen/vegetation/climate relationships have not changed fundamentally over the last $1.3 \mathrm{Ma}$ (Heusser and Morley 1985; Heusser, 1989), a simplistic summary of climates inferred from the pollen assemblages in Holes 798A, 798B, and $798 \mathrm{C}$ is that interglacial climates on the eastern shore of the southern Sea of Japan were warm and humid, climates of glacial maxima were cool and dry, and intervening climates changed frequently in a complex manner between these end-members. The nature and timing of the climatic variations inferred from pollen in the Sea of Japan are similar to and synchronous with contemporaneous Japanese climatic reconstructions onshore (Miyoshi, 1989a,b; Heusser and Morley, 1990). Unlike the climate of some other parts of Japan, such as northern Hokkaido or the heights of the Japanese Alps (Tsukada, 1967, 1983; Igarashi and Kumano, 1981; Igarashi, 1990), the mean regional climate of southwestern Japan remained temperate or cool temperate, at least for the duration of time represented in our sampling intervals. Changes in seasonality are implicit in the shifting compositions of vegetation. For example, the cooccurrence of warm temperate and cool temperate elements in early Pleistocene macrofossil assemblages from southwest Japan has been interpreted as evidence of warm winters and cool summers (Momohara et al., 1990).

The nature and timing of northeast Asian climatic changes inferred from pollen in marine sediments in the Sea of Japan are similar to global climatic changes (Heusser and Morley, in press; Heusser and Morley, unpubl. data), as suggested by indirect correlation of other paleoclimatic indicators (Fuji, 1988; Hovan et al., 1989; Ingle, Suyehiro, von Breymann, et al., 1990; DeMenocal, this volume). Spectral analysis of pollen data from the northwest Pacific shows a systematic relationship between summer monsoon variability on Japan (as monitored by Cryptomeria), precession, and maximum summer insolation over the last 350 k.y (Heusser and Morley, in press). Correlative late Quaternary pollen data from Site 798 should reflect similar periodicities.

\section{Comparison with Marine Paleoenvironmental Data from Legs 127 and 128}

The systematic fluctuations in other components and properties of sediment deposited at Site 798 are strikingly illustrated by the light/dark 

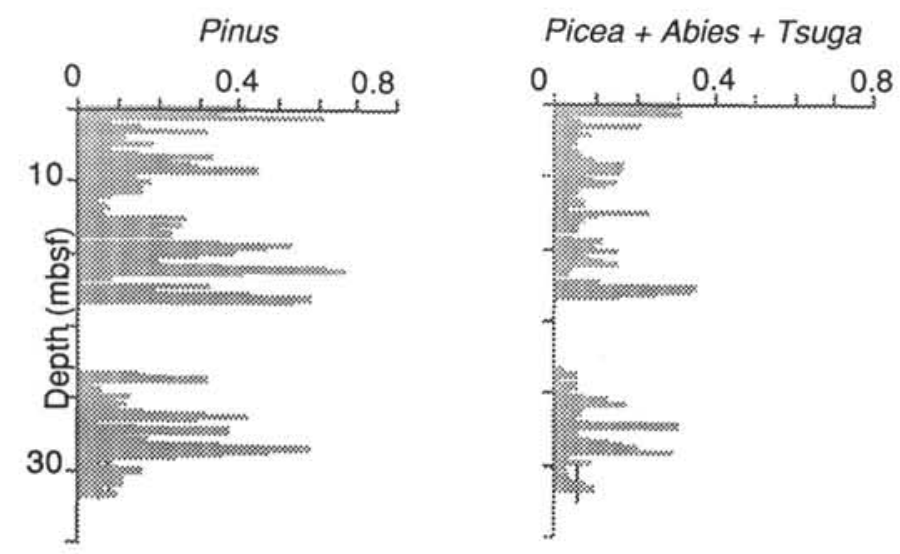
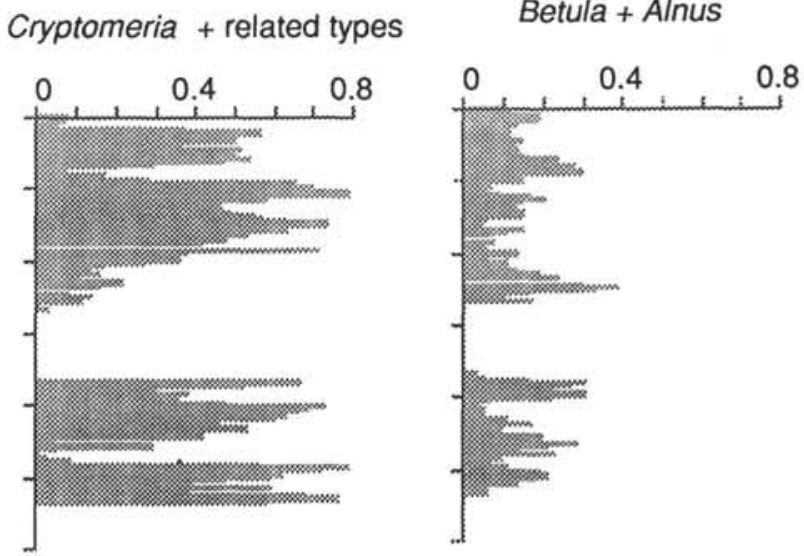
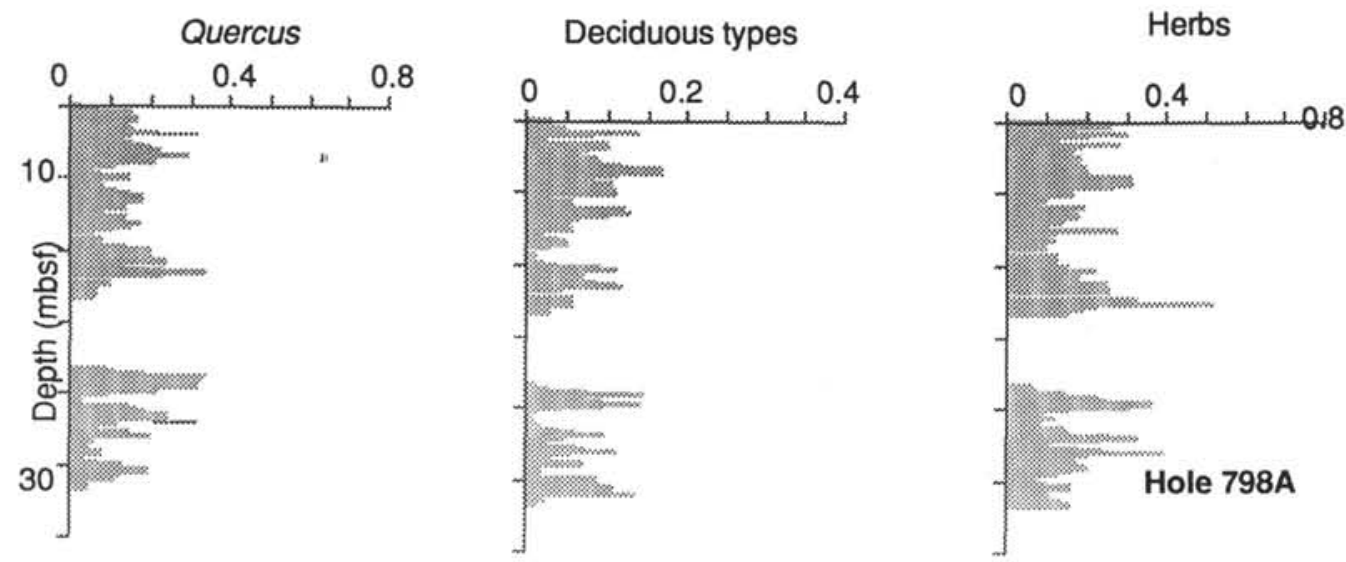

Figure 4. Percentages of selected pollen types from Sections 798A-1H through 798A-3H plotted against depth.

color changes of approximately the last 1 m.y. (Ingle, Suyehiro, von Breymann, et al., 1990). Many of these variations were attributed to but not directly correlated with climatic change because of the complexity of paleoclimatic and paleoceanographic relationships. Specific correlations were made between the spectral gamma-ray (SGR) log, which was interpreted as reflecting eolian input of terrigenous material (presumably loess from China) and climatic forcing (Ingle, Suyehiro, von Breymann, et al., 1990; DeMenocal, this volume).

Climatic interpretations of fluctuations in percent terrigenous matter (Ingle, Suyehiro, von Breymann, et al., 1990) and in pollen data from identical subsets of samples from Cores 798B-13H through $15 \mathrm{H}$ often differ. For instance, evidence of enhanced summer monsoon intensity during interglacials inferred from peaks of Cryptomeria pollen (Heusser, 1989 , in press) sometimes corresponds to evidence of arid glacial climates and enhanced winter monsoons inferred from terrigenous peaks (Ingle, Suyehiro, von Breymann, et al., 1990; DeMenocal, this volume).

A similar disparity between paleoclimatic reconstructions from lithologic and from palynologic components of sediments from Site 798 is apparently seen in a comparison of the interpretations of the preliminary pollen data and "darkness" measurements from the upper $13 \mathrm{~m}$ of Hole 797B. In those four samples, which were analyzed for both pollen (Heusser, this volume) and color (Tada et al., this volume), the two interglacial pollen samples do not correspond to dark "sapropel" layers, which are referred to as interglacials (Tada et al., this volume).

As suggested here and in the Initial Reports (Ingle, Suyehiro, von Breymann, et al., 1990), Pliocene-Pleistocene sediments from the Sea of Japan contain a unique inventory of marine and terrestrial paleoenvironmental indicators. Unraveling the complexities of the paleoenvironmental changes in and around the Sea of Japan deserves further detailed paleoecologic and chronostratigraphic research.

\section{REFERENCES}

Fuji, N., 1988. Palaeovegetation and palaeoclimate changes around Lake Biwa, Japan during the last ca. 3 million years. Paleolimnol. Lake Biwa Jpn. Pleistocene, 7:21-28.

Heusser, L., 1977. Pollen distribution in the northeast Pacific Ocean. Quat. Res., 7:45-62.

, 1988. Pollen distribution in marine sediments on the continental margin off Northern California. Mar. Geol., 80:131-147.

1989. Northeast Asian Climatic Change over the last 140,000 years inferred from pollen in marine cores taken off the Pacific Coast of Japan. In Leinen, M., and Sarnthein, M. (Eds.), Paleoclimatology and Paleometeorology: Modern and Past Patterns of Global Atmospheric Transport: Dordrecht (Kluwer), 665-692.

Heusser, L., and Morley, J. J., 1985. Pollen and radiolarian records from deep-sea core RC14-103: climatic reconstructions of northeast Japan and northwest Pacific for the last 90,000 years. Quat. Res., 24:60-72.

, 1990. Climatic change at the end of the last glaciation in Japan inferred from pollen in three cores from the Northwest Pacific Ocean. Quat. Res., 34:101-110.

-, in press. Variations in northeast Asian environments over the last 350,000 years reconstructed from pollen records of Cryptomeria japonica (Japanese cedar) in piston cores from the northwest Pacific Ocean. PACLIM, Cal. Dept. Water Res.

Hovan, S. A., Rea, D. K., Pisias, N. G., and Shackleton, N. J., 1989. A direct link between the China loess and marine $\delta^{18} \mathrm{O}$ records: aeolian flux to the north Pacific. Nature, 340:296-298. 
Igarashi, Y., 1990. Forest history constructed from fossil pollen-30,000 years in Hokkaido. J. Jpn. For. Soc. Hokkaido, 38:1-9.

Igarashi, Y., and Kumano, S., 1981. Vegetational changes during the last glacial age in Hokkaido. Quat. Res. Jpn., 20:129-141.

Ingle, J. C., Jr., Suyehiro, K., von Breymann, M. T., et al., 1990. Proc. ODP, Init. Repts., 128: College Station, TX (Ocean Drilling Program).

Kondo, T., Igarashi, Y., Yoshida, M., and Akamatsu, M., 1984. Quaternary deposits in the borehole at Shizukawa, Tomakomai City, Hokkaido, Japan. Quat. Res. Jpn., 22:313-325.

Koroneva, E. V., 1961. Investigation by method of pollen and spore analysis of two marine cores from the Sea of Japan. Oceanogr. T. Geol. Inst. Academy Sci. USSR, 126:1-16.

Miyoshi, N., 1989a. Preliminary pollen analytical study of a late-Pleistocene deposit from Tokusa Basin, Yamaguchi Prefecture. Quat. Res. Jpn. 28:41-48.

, 1989b. Vegetational history of the Hosoike Moor in the Chugoku Mountains, western Japan during the Late Pleistocene and Holocene. Jpn. J. Palynol., 35:27-42.

Miyoshi, N., Yano, N., and Hada, Y., 1976. Pollen analysis studies of moor sediments in Chugoku, Japan 3. Kabasaka moor (Hyogo Pref.). Bull. Hiruzen Res. Inst., 2:1-10.
Picea + Abies + Tsuga

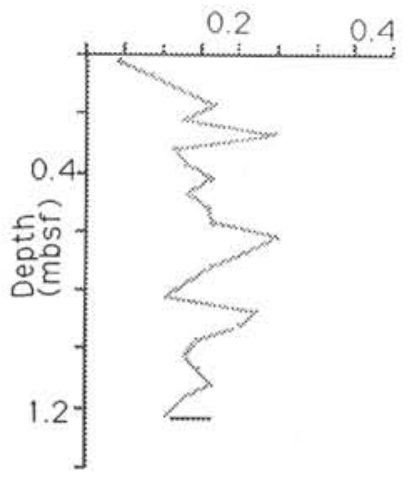

Cryptomeria
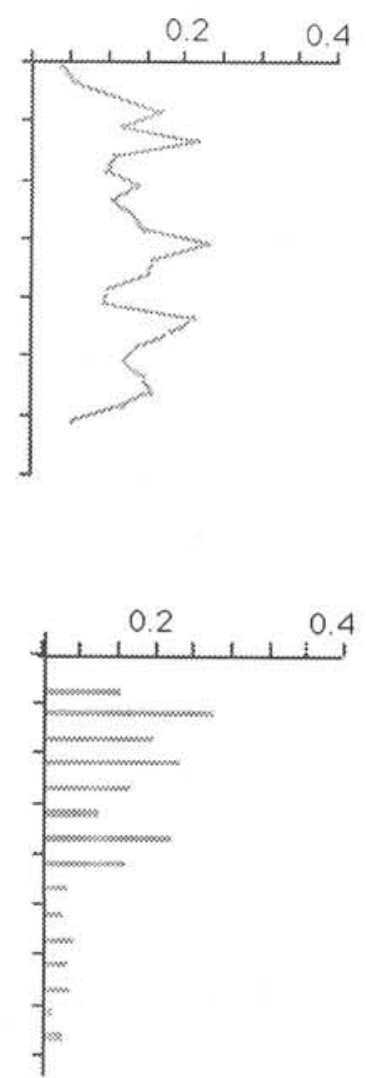

4
Momohara, A., Mizuno, K., Tsuji, A., and Kokawa, S., 1990. Early Pleistocene plant biostratigraphy of the Shobudani Formation, southwest Japan, with reference to extinction of plants. Quat. Res. Jpn., 29:1-19.

Morley, J., Heusser, L., and Sarro, T., 1986. Latest Pleistocene and Holocene palaeoenvironment of Japan and its marginal Sea. Palaeogeogr., Palaeoclimatol., Palaeoecol., 53:349-358.

Numata, M., 1974. The Flora and Vegetation of Japan: New York: (Elsevier). Ohwi, J., 1984. Flora of Japan: Washington (Smithsonian Inst).

Sarro, T., 1991. Quaternary paleoecology of Japan: evidence from marine palynology [Ph.D. dissert.]. New York Univ., New York.

Tsukada, M., 1967. Pollen succession, absolute pollen frequency and recurrence surface in central Japan. Am. J. Bot., 54:821-831.

1983. Vegetation and climate during the last glacial maximum in Japan. Quat. Res., 19:212-235.

, 1988. Japan. In Huntley, B., and Webb, T., III (Eds.), Vegetation History: Dordrecht (Kluwer), 459-518.

Date of acceptance: 22 January 1992

Ms 127/128B-138
Date of initial receipt: 19 March 1991
Quercus
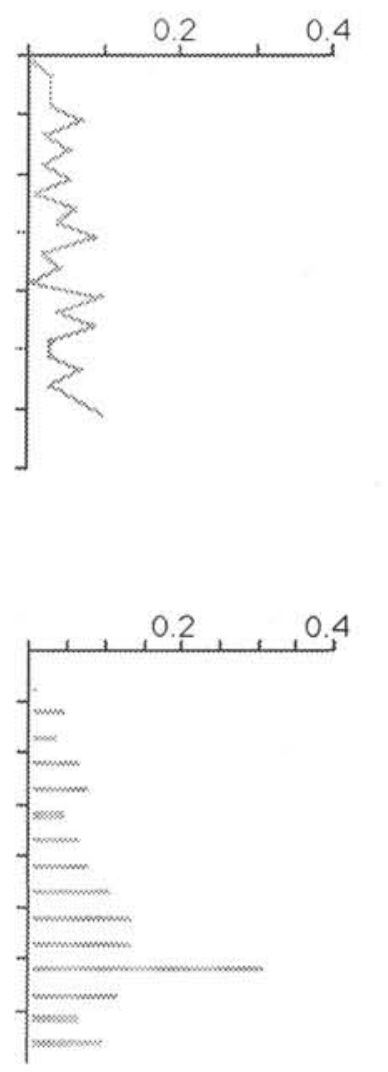

$0,2,0.4$

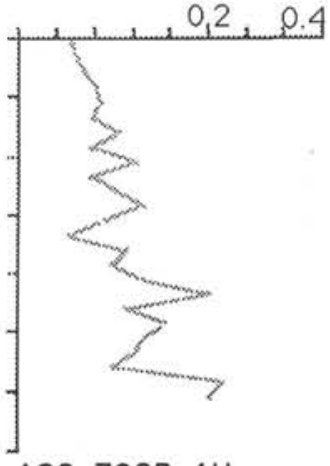

Core $128-798 \mathrm{~B}-1 \mathrm{H}$
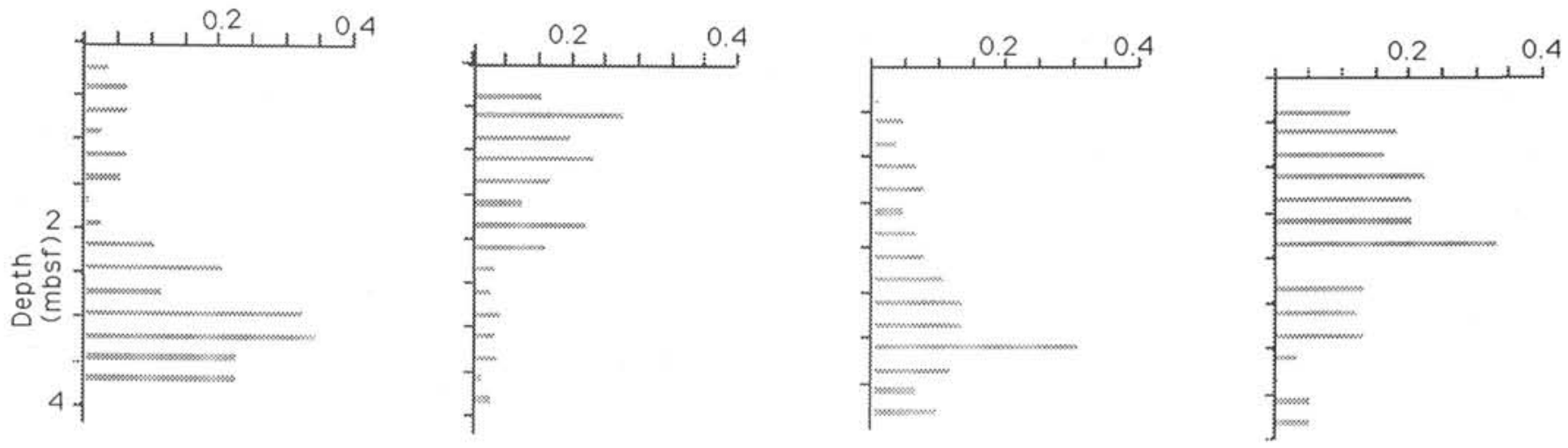

Core $128-798 \mathrm{C}-1 \mathrm{H}-3 \mathrm{H}$

Figure 5. Percentages of selected pollen types from Core 798B-1H-1, 0-125 cm (upper), and in Sections 798C-1H through 798C-3H (lower) plotted against depth. 

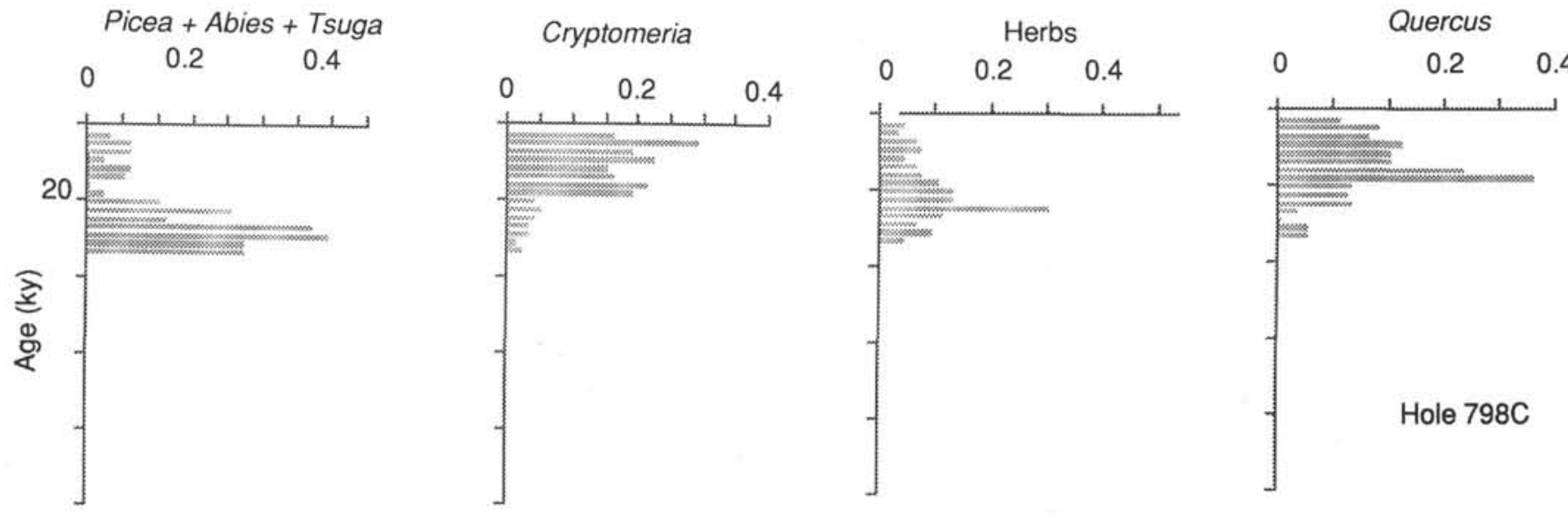

Figure 6. Percentages of selected pollen taxa from Hole 798C plotted against age.

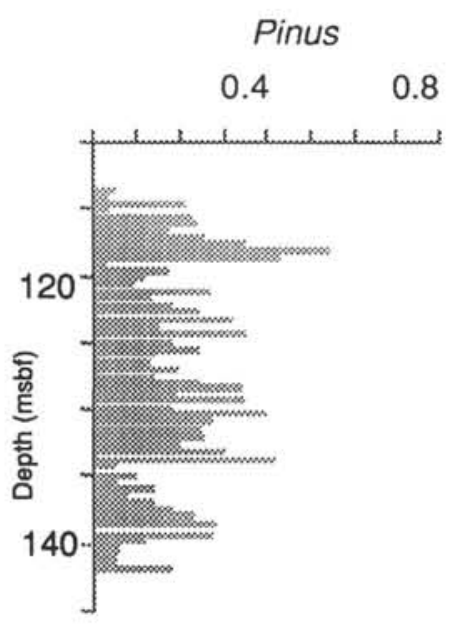

Cryptomeria

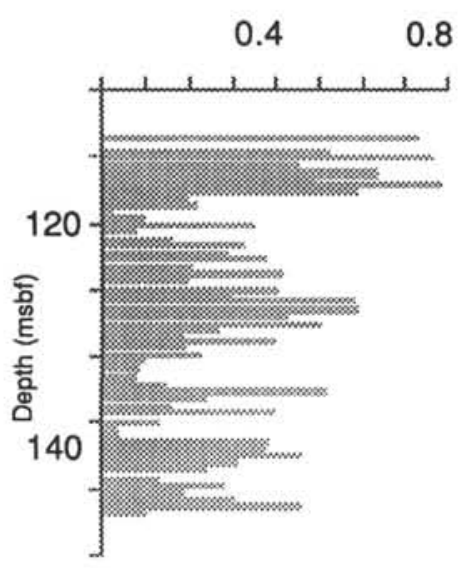

Picea + Abies + Tsuga

$0.4 \quad 0.8$

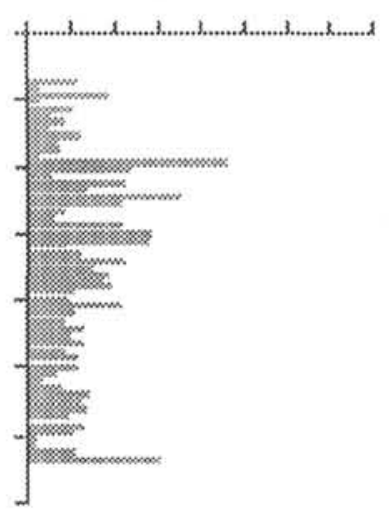

Quercus

$0.4 \quad 0.8$

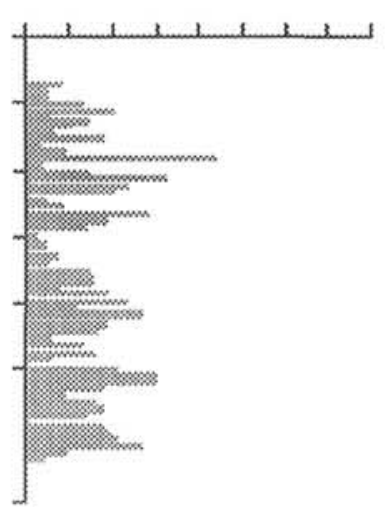

Betula + Alnus

0.4

0.8

0.4 0.8
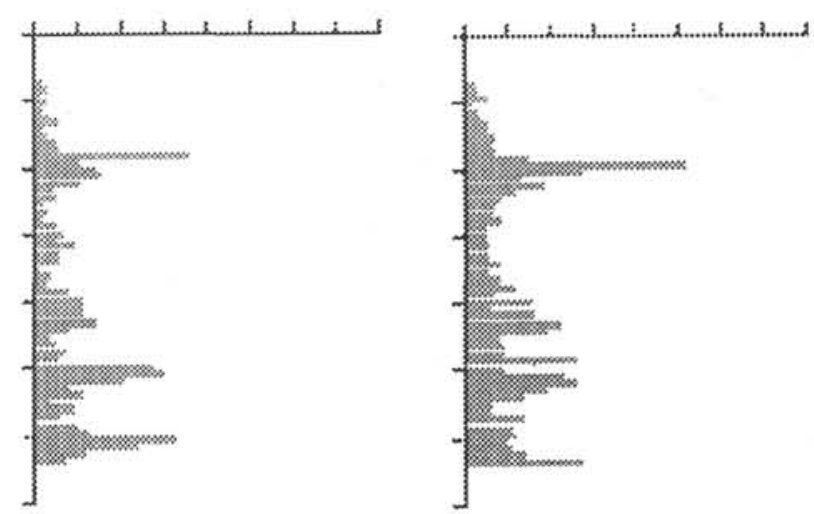

Deciduous types (excluding Quercus)

0.2

0.4

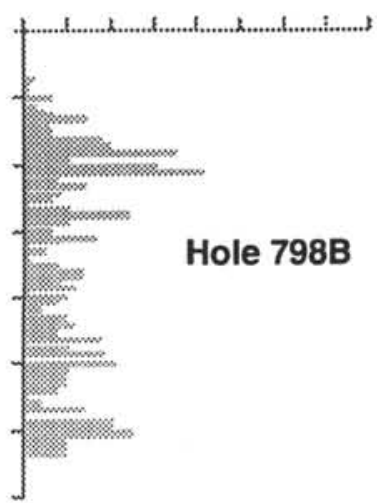

Figure 7. Percentages of selected pollen taxa from Hole 798B plotted against depth. 
Total Pollen

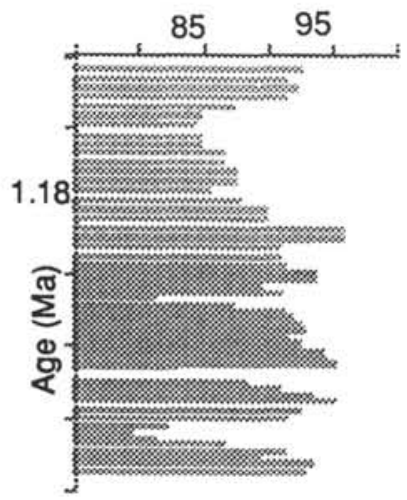

$\%$ Terrigenous
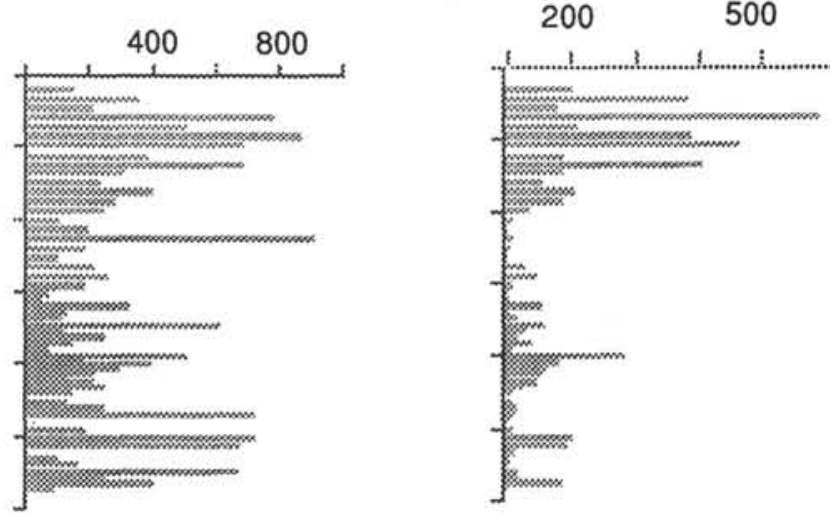

Pollen Concentration

(x100)
Picea + Abies + Tsuga

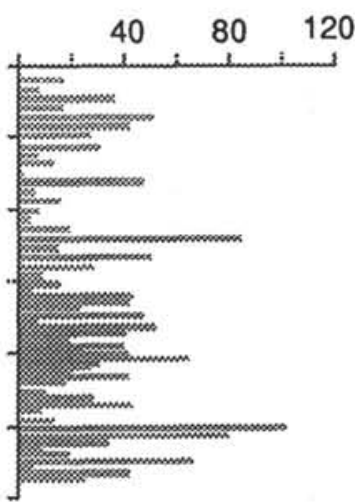

Hole 798B

Figure 8. Concentration of selected pollen taxa from Hole 798B plotted against age. 